\title{
Self Acceptance In Adolescent Teachers As A Result Of Pregnancy (Case Study In Kebonbatur Demak Village)
}

\author{
Anis Syahadatil Laili ${ }^{\mathrm{a}}$ \\ ${ }^{\text {a }}$ Semarang State University, Taman Siswa Street, Semarang, Indonesia \\ Corresponding e-mail: anissyali2@gmail.com
}

\begin{abstract}
In terms of expressing sexual feelings, many teens behave sexually even without marriage bonds. So the phenomenon of teenagers who become pregnant out of wedlock more and more occur when they are not ready to get pregnant, so experiencing various difficulties including in terms of self-acceptance. The purpose of this study was to determine the image of self-acceptance of teenagers who married due to unwanted pregnancies. Using qualitative methods with case study approach. The main informants in this study are 2 teenagers while secondary sources are 1 parent and 1 community leader. Data collection techniques used in-depth interviews with qualitative data analysis methods. The results of the research obtained the picture that the first subject can accept himself. While the second subject still can not accept himself. Suggestions proposed for the family is to provide protection and support both moral and material. For the general public that is not always a negative view of the late teens who married due to pregnancy out of wedlock and inculcate moral values and religion in adolescent life.
\end{abstract}

Keywords: teenagers, pregnant out of wedlock, self-acceptance.

\section{INTRODUCTION}

Adolescence is a transitional period of development between childhood and adulthood involving biological, cognitive and socio-emotional changes [1]. In this transitional period, adolescents have a high curiosity, are looking for identity, emotional labile and need a direction, want to be considered a group that is already independent and responsible. According to Santrock [1] adolescence begins around the age of 10 to 13 years and ends at around the age of 18 to 22 years. Santrock [1], adolescence is characterized by major changes such as the need to adapt to physical and psychological changes, identity search and Forming new relationships including expressing sexual feelings. In this process of transition there are problems teenagers face due to changes that occur, whether physical, cognitive and socio-emotional.

One of the problems that occurs because of the interaction between physical changes, cognitive and socio-emotional problems is sexual. This sexual drive is so high that it often creates physical and psychic tension. So that teenagers try to express sex drive such as dating, making out sex contact. At this time adolescents experience puberty, the sexual organs in adolescents have begun to mature both girls and boys. In addition, the hormones in the adolescent body also began to develop, causing sexual urges in adolescents.

Adolescents should strive to achieve their developmental tasks well in line with norms and rules in society, but today many teenagers are caught in expressing their sexual feelings wrongly resulting in violations of community norms due to the expression of sexual urges. Many teenagers express sexual feelings with direct sexual behavior. They behave sexually as adults, but that is not the time to be done by teenagers. According to BKKBN data, $63 \%$ of juvenile and junior high school adolescents in Indonesia have had sex. According to the Director of Youth and Protection of Reproductive Rights of BKKBN, M Masri Muadz, the data was the result of a survey by a survey agency taking samples in 33 provinces in Indonesia in 2008. This figure is up compared to previous years. Based on the 20052006 study in big cities from Jabotabek, Medan, Jakarta, Bandung, Surabaya and Makassar, found around $47 \%$ to $54 \%$ of adolescents admitted to having sex before marriage. While premarital sex in jateng rose 7-fold. Even the latest data shows teenagers aged 15 years to 19 years also never feel sex outside of marriage. Data from one district in Central Java mentioned 70 out of 70 marriages a year, 37 of whom were pregnant out of wedlock. (Tribunjateng, Thursday 14 november 2013) 
Some teenagers have sexual relations other than a factor of high sex drive in adolescence is the unstable emotion so that the teenager is difficult to control himself. Because it can make teens behave according to their own will such as melakuakan sexual contact and can result in pregnancy out of wedlock. As a result of this teen pregnancy will cause some conflicts in adolescent self. According Sumapradja (1981: 145), teenage pregnancy is generally a catastrophe that destroys the strength, agility, intelligence and ideals of adolescents in question. Pregnant teenagers are exposed to high risk, both from a medical standpoint, and from a societal point of view.

After a pregnancy in adolescent due to sexual intercourse, then will be sought solution of the problem. There are several solutions that can be done that is married and not married. Teens and parents who have moral and normative responsibility will choose the first solution. While on the second solution is usually teenagers exiled or have an abortion.

Though marriage (marriage) is a sacred bond between a couple from a man and a woman who has stepped on or considered to have a fairly old age. Marriage is considered a bond because the couple's relationship between a man and a woman has been legitimately recognized in religious law

Readiness in a marriage is necessary both in terms of social life, economic, physiological, and psychological. But there are some problems faced by girls who are married because of unwanted pregnancies because they are less prepared in marriage. According to Papilia [2] pregnant or having children sebemum married could be the cause of divorce. This indicates that an unmarried pregnancy will cause Problems both before the wedding and after the wedding. Other issues include childhood and adolescent loss, loss of personnel freedom, and lack of opportunity to develop full sense of self as well as denial of psychosocial and emotional wellbeing, reproductive health, opportunities for a higher level of formal education, a sense of regret and acceptance self.

In fact, teenagers who are pregnant out of wedlock and want to maintain their pregnancy may be disrupted in their social and economic conditions and also in their psychological condition. Psychological burden will increase when teenagers who experience an unmarried pregnancy are married. Obligations as a wife and expectant mother need a big responsibility to make teenagers are more burdened.

Social norms that develop in the neighborhood where teenagers are married due to pregnancy outside of marriage can also affect the psychological state of the teenager. Teens who are pregnant out of wedlock are often blasphemed, rejected, considered as a disgraceful bearer or gossip in their environment. Even worse, some of them are excommunicated by the family and society and become the talk of the surrounding community even considered as a disgrace for society and the environment.

Pregnancy outside the marriage can be said from various aspects usually do not have the readiness for the change in him even possible to receive the womb. In addition, marriage that begins with an extramarital pregnancy is vulnerable to problems and conflicts because they are both immature and not yet ready to assume parental responsibilities, and sometimes the marriage is difficult to maintain, often ending in divorce.

These things can make teenagers do not accept the situation itself, so the psychological problems experienced by teens become more severe and resulted in teenagers who married because unwanted pregnancies more difficult to accept himself.

\section{PURPOSE}

The purpose of this study was to determine the self-acceptance picture of teenagers who married due to pregnancy out of wedlock.

\section{BENEFITS OF RESEARCH}

\subsection{Theoretical benefits}

The theoretical benefits of this study are expected to enrich science especially in the field of Developmental Psychology, where at this time the individual faces the task of development related to the formation of intimate relationships with others. As well as Social Psychology related to the phenomenon of teenagers who are pregnant out of wedlock.

\subsection{Practical Benefits}

With the description of self-acceptance of adolescent married due to pregnancy outside marriage, this research is expected to provide input and information for parents, educators and other individuals, especially teenagers about the importance of controlling their sex drive so that there is no pregnancy outside of marriage.

\section{LITERATURE REVIEW}

\subsection{Self Acceptance}


According to Helmi (1998: 55) selfacceptance is the extent to which a person can realize and profess personal characteristics and use them Whereas according to Hurlock (1974: 30) self acceptance is the extent to which an individual is able to realize the characteristics of his personality and is willing to live with those characteristics. Selfacceptance can be interpreted positive attitude of the individual is shown with a sense of pleasure and satisfaction of himself, accept the state of self, facts, reality, both physically and psychologically with all the weaknesses and advantages that exist in self without any sense of disappointment and trying to develop themselves as optimally as possible.

There are several aspects of self-acceptance, according to Grinder in Parista (2008: 48) aspects of self-acceptance include:

1) Physical Aspects

Individual satisfaction with body parts and overall physical appearance describes physical acceptance as an evaluation and self-assessment of the body, whether the body and appearance are pleasant or satisfactory to accept or not.

2) Psychic Aspects

Individuals who can accept themselves as a whole and have confidence in the ability of themselves in facing the demands of the environment.

3) Social Aspects

The individual accepting himself socially will have the belief that he is equal to the other so that the individual is able to position himself as others are able to position themselves.

4) Moral Aspects

Moral development in the self is viewed as a process that involves the structure of individual thinking in which individuals are able to make decisions wisely and able to account for decisions or actions that have been experienced based on the existing social context.

In addition, the individual who can accept himself also has certain characteristics, Sheere in Cronbach (1963: 33) the characteristics of a person who is willing to accept themselves are:

1) Have confidence in his ability to face his life.

2) Consider himself worthy as a human being who is equal to other people.

3) Dare to take responsibility for his behavior.

4) Accepting reproach and praise objectively.

5) Do not blame him or herself for his limitations Denying its advantages.

\subsection{Teenagers}

According to the World Health Organization (WHO), adolescents (adolescence) are those aged 10-19 years. In other terminology the United Nations mentions youth for those aged 15-24. This is then incorporated into a terminology of young people covering 10-24 years. Meanwhile, in the BKKBN program mentioned that teenagers are those aged between 10-24 years.

\subsection{Marriage}

According to Law No.1 / 1974 marriage / marriage as the inner bond between a man and a woman as husband and wife with the aim of forming a happy and eternal family (household) based on Belief in the One Supreme (in Walgito, 2004: 34) .

Soemiyati (1999: 14) states the purpose of holding a marriage as an inner and outer bond, the way of obtaining offspring, the fulfillment of biological needs, maintaining humanity from evil and destruction, and when viewed from the aspect of society as a function of familiarization of the family.

4. Unwanted Pregnancy

Unintended pregnancy is a pregnancy event that occurs when the spouse (male and female) has not yet married, has not been legalized by the marriage institution to form a household (Srijauhari, 2008: 12).

\section{RESEARCH METHODS}

The research used qualitative research type. The approach used is a case study approach. The method used in this research is interview method. Data obtained from 4 subjects, subjects 1 and 2 taken from the initial study that has been done by researchers, from the results of preliminary studies of researchers through observation and initial interviews in the Village Kebonbatur Mrangen Demak. From the study were taken 2 subjects who meet the kretria as primary speakers and 2 subjects as the subject of witnesses or secondary sources .. The method of data analysis used in this study is the method of qualitative data analysis

\section{RESULTS AND DISCUSSION}

In the first major subject according to the results of the interview known to know about the subject's identity that the subject was just 16 years old when married and still in second grade of high school, from the interview also revealed about the incident related to pregnancy subject. Reveals her pregnancy to her parents. She became very sad and reserved and could not accept her pregnant state. Here the 
parents are very helpful to accept the subject's self, the parents are not directly angry and judge the subject of the experience experienced. But the subject is still difficult in accepting the circumstances of her pregnant outside of marriage, the subject tried to forget the mortgage, when asked the subject just answering sober. Subjects are still very dependent with their parents in solving problems faced. Early marriage is also very difficult for subjects ranging from economic problems to inlaws. But in the end the subject can accept himself which means, accepting the state of self, facts, reality, both physically and psychologically with all the weaknesses and strengths that exist in the self without any sense of disappointment and trying to develop themselves as optimally as possible.

For the second subject, he feels very sorry for his actions pregnant out of wedlock, especially by deliberately he did it just so he agreed to marry the couple. The condition of the marriage is very heavy, he has a husband who is very stubborn and like to set up, the economic conditions are not too good, the relationship with parents is also not good, even until now the parents have not approved marriage sujek with his partner. Subject relationship with in-laws is also not good, here the subject is very sad over the incident. At the beginning of the marriage he was happy but over time he felt disappointed with his marriage, his mudannya like snatched, he still want to walk the road like the old days. But the subject tried to accept all that and try to be patient with hope his marriage will change better. The subject has not been able to accept his and her marriage and he is still very sorry for the accidental pregnancy because he wanted to get the blessing from parents.

Community leaders know about their married pregnant citizens from neighbors who talk about the subject. Talks from neighbors make the subject difficult to accept his situation because it is rejected by society and make people embarrassed. Moreover, what happens to the subject that neighbors always know the story of the incident that happened to him. The community tries to give good advice through his parents who make the subject more receptive to his situation.

\section{CONCLUDE AND ADVICE}

\subsection{Conclude}

The first major subject at first had not been able to accept her pregnant circumstances outside of marriage. She was afraid, sad and being quiet. Early marriage is also very difficult for the subject ranging from economic problems to in-laws. But with the acceptance of parents on him and all the help of the subject parents began to receive his marriage
The second major subject has a more complicated problem than the first subject. At the beginning of the wedding he was happy but after that there are things that hurt him. Starting from the problem of husband, parents, in-laws, finances and problems with neighbors. But he tried to accept the situation and be patient with the hope of change.It does not regret already married because it happened but he was very sorry because he was pregnant out of wedlock deliberately to get the blessing Of parents.

\subsection{Advice}

1) For teenagers who married due to pregnancy outside of marriage in order to accept his situation thoroughly so as to achieve a life that is useful for themselves, family and the environment.

2) The family can provide moral support for late teenagers who have an unmarried pregnancy

3 ) For the general public not to always have a negative view of the late teens who married due to pregnancy out of wedlock seta instilling moral values and religion in adolescent life.

4) For further researchers to complete and refine this research.

\section{REFERENCE}

[1] Santrock, J. W. (2007). Remaja Edisi 11 Jili 1. Jakarta: Erlangga

[2] Papalia, D. E., Old, S. W., \& Feldman, R. D. (2008). Human Development (Psikologi Perkembangan) Edisi Kesembilan. Jakarta: Kencana Prenada Media Group

[3] Agustian, H. (2009). Psikologi Perkembangan. Bandung: PT Refika Aditama.

[4] Azwar, S. (2016). Metodelogi Penelitian. Semarang: Pustaka Pelajar.

[5] Baron, R. A., \& Bryne, D. (2003). Psikologi Sosial Jilid 1 Edisi Kesepuluh. Jakarta: Erlangga.

[6] Lestiani, F., \& Safira, S. I. (2015). Penerimaan Diri Remaja Cerebral Palsy. Character, 6-13.

[7] Muhadjir,Noeng.(2000).Metodelogi Penelitian Kualitatif Edisi IV.Yogjakarta: Rake Sarasin

[8] Santrock, J. W. (2012). Life-Span Development Perkembangan Masa Hidup Edisi Ketigabelas Jilid 1. Jakarta : Erlangga.

[9] Resti, G. T. (2016). Pengruh Penerimaan Diri terhadap Harga Diri Remaja di Panti Asuhan Putri Aisyah Yogjakarta. Jurnal Bimbingan \& Konseling Edisi 1, 1-12. 